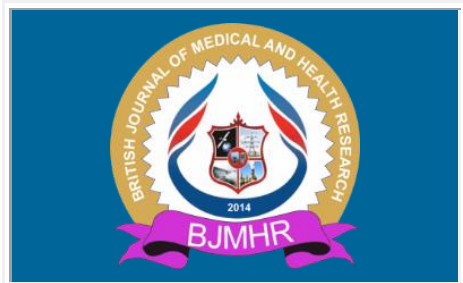

\title{
BJMHR
}

British Journal of Medical and Health Research

Journal home page: www.bjmhr.com

\section{Homeopathic Pharmacy's Legislation in India- A Review}

\section{Bhagyashri D. Nagare*1, Yogesh V. Ushir ${ }^{2}$}

1.Research Scholar; Atal Bihari Vajpayee Homeopathic Medical College and Hospital, Aurangabad-Ahmednagar- Pune Hwy, Jalke Bk., Maharashtra 414603, India.

2.Principal; SMBT Institute of Diploma Pharmacy, Dhamangaon, Tal. Igatpuri, Dist.

Nashik, Maharashtra 422403, India.

\section{ABSTRACT}

Homeopathy is a popular traditional alternative system of medicine. There is no review in literature reporting the Homeopathic pharmacy legislation in India, so this review was written to provide a rapid overview regarding homeopathy medicines and pharmacy legislations within India. The review mainly covers origin, evolution and development of pharmacy within India in pre independence and post independence era. In India, the Homeopathic pharmacy mainly governs by The Drug and Cosmetic Act 1940 and Rules 1945. The question that, who regulate the homeopathy in India? also cover in review. The Central Council of Homeopathy $(\mathrm{CCH})$ is a statutory body under the Ministry of AYUSH, Government of India regulate Homeopathy.

Keywords: Pharmacy Legislations, Homeopathy, Central Council, Ministry of AYUSH. 


\section{INTRODUCTION}

Homeopathic medicines are prepared from different sources i. e. plants, animals, minerals, nosodes, sarcodes, imponderabilia and synthetic medicines. Homeopathic medicines can be prepared under different scales of potentization i.e. decimal, centesimal and 50 millesimal. Homeopathic medicines are proved on healthy subjects to obtain a remedy picture. Homeopathic medicines are administered in minimum doses to sick person on basis of similarity to bring cure (Ernst E., 2002; Tayyeba Rehman, et al., 2017). Homeopathy is an alternative system of medicine. Homeopathy is based on similar principle 'Similia similibus curentur' that means diseases are cured by symptom similarity. Homeopathy was discovered in 18th century by a Germen physician, Dr. Christian Fredrick Samuel Hahnemann. The "Homeopathy" word is derived from two Greek words: 'homeos' and pathos means 'similar and 'suffering' respectively. So, it can be defined as the therapeutic method of treating the diseases based on the symptom similarity (Mukherjee PK, et al., 2006).

Homeopathy has its own importance in various diseases and disorder (Wayne JB., 2000). Not to discussing many more about Homeopathic medicines importance just one example is sufficient; Ministry of AYUSH on $06^{\text {th }}$ March 2020 suggested 'Arsenicum album 30' - a Homeopathic medicine for Preventive and prophylactic of COVID-19 like illnesses.

They stated that,

'Arsenicum album 30, daily once in empty stomach for three days. The dose should be repeated after one month by following the same schedule till Corona virus infections prevalent in the community. In one of the studies Arsenic album as one of the constituents in a formulation affected HT29 cells and human macrophages. Also, it showed .j.NF-KB hyperactivity (reduced expression of reporter gene GFP in transfected HT29 cells), .J,TNF-a release in macrophages. More over Arsenic album is a common prescription in the cases of respiratory infections in day to day practice' (Ministry of AYUSH, 2020).

Although we aware about system the question is in mind how, who, where the Homeopathic medicines regulated within India? Here is the answer in this further section of review.

\section{Homeopathic Medicine}

Homeopathic medicines include any drug which is recorded in Homeopathic proving or the therapeutic efficacy of which has been established through long clinical experience as recorded in authoritative Homeopathic literature of India or abroad and which is prepared according to techniques of Homeopathic Pharmacy but does not include a medicine which is administered by parentral route (Ram Jyothis, 2020).

\section{Registered Homeopathic Medical Practitioner}

Means, a person who is registered in the Central Register or State Register of Homeopathy. 


\section{Manufacture, sale and distribution of Homeopathic medicines are governed by}

Drugs and Cosmetics Act, 1940 (Act 23 of 1940) and its amendments

Drugs and Cosmetics Rules, 1945 and its amendments

Narcotic Drugs and Psychotropic Substances Act and Rules, 1985 (Act 81 of 1985)

Drugs and Magic Remedies (Objectionable Advertisements) Act, 1954 (21 of 1954)

Drugs and Magic Remedies (Objectionable Advertisements) Rules, 1955

Medicinal and Toilet Preparations (Excise Duties) Act, 1955 (Act16 of 1955)

Drugs (Prices Control) Order, 1995

\section{Drugs and Cosmetics Act, 1940}

It was passed on 10th April, 1940; to regulate the import into, manufacture, distribution and sale of drugs and cosmetics in the country. It contains: 6 Chapters - Chapter I, Chapter II, Chapter III, Chapter IV, Chapter IVA, and Chapter V.

2 Schedules - First Schedule and Second Schedule

Chapter I: Introductory - Short title, extent, commencement, definitions, etc.

Chapter II: Drugs Technical Advisory Board, Central Drugs Laboratory, and Drugs Consultative Committee

Chapter III: Import of Drugs and Cosmetics

Chapter IV: Manufacture, Sale and Distribution of Drugs and Cosmetics

Chapter IVA: Provisions Relating To Ayurvedic, Siddha and Unani Drugs

Chapter V: Miscellaneous

First Schedule:

Part A - Ayurvedic and Siddha Systems

Part B - Unani Tibb Systems

Second Schedule: Standards To Be Complied With By Imported Drugs and By Drugs Manufactured For Sale, Stocked/Exhibited For Sale/Distributed (Kuchekar BS, 2008; Singh SK et al., 2017).

Table 1: Drugs and Cosmetics Act 1940 and Rules 1945 in view of Homeopathic Pharmacy.

\begin{tabular}{lll}
\hline Part & Rule & Content \\
\hline VI-A & From Rule 67-A to Rule 67-H & Sale Of Homeopathic Medicines \\
VII - A & From Rule 85-A to Rule 85HH & Manufacture for Sale of Homeopathic Medicines \\
IX-A & From Rule 106-A to Rule 106-B & Labeling And Packing of Homeopathic Medicines \\
\hline
\end{tabular}

PART VI-A: SALE OF HOMEOPATHIC MEDICINES (Mandal, PP. et al., 2019; Goel, 2016; Anonymous, 2020)

\section{RULE 67A:}

(1) Licensing authority appointed by State Govt. 
(2) Application for the grant / renewal of a licence in Form 19B, with a fee of Rs.250/within 6 months of expiry with a fee of Rs.250/- + Rs.50/- after 6 months of expiry

(3) If damaged/Lost duplicate copy on Rs 50/-

\section{RULE 67B:}

Power to sign licenses and such other powers to any person under the control of licensing authority with the approval of the State Govt. www.experthomeo.com

\section{RULE 67C:}

Forms of licenses to sell drugs Licence issued in Form 20C / 20D

\section{RULE 67D:}

Sale at more than one place Application for an issue of separate licence in respect of each place.

\section{RULE 67E:}

Duration of licence $5 \mathrm{yrs}$. from the date it is granted / renewed

\section{RULE 67EE:}

Certificate of renewal Application for renewal of Form 20C and 20D Licence issued in Form $20 \mathrm{E}$

\section{RULE 67F:}

Conditions to be satisfied before a licence granted;

1. Premises are clean and the sale premises are in charge of a person who has been dealing in Homeopathic Medicines

2. Any person, if aggrieved by the Licensing authority may within 30 days from the grant of the receipt of such order appeal to the State Govt.

\section{RULE 67G:}

Conditions of licence.

1. Premises for sale of medicines clean

2. Sale to be conducted under the supervision of a person competent to deal in Homeopathic medicines

3. To permit an Inspector to inspect and furnish such information as he may require.

4. To maintain records of purchase and sale of Homeopathic medicines containing alcohol with names and addresses of parties.

5. To maintain records of purchase and sale of Homeopathic medicines containing alcohol over 30ml for potent medicines and 60ml for Qs (Quantum satis -Mother tincture).

6. To maintain an Inspection Book in Form 35 to enable an Inspector to record his impressions.

\section{RULE 67GG:}

Additional information to be furnished Documentary evidence in respect of the ownership/ occupation on rental / other basis of the premises. www.experthomeo.com 


\section{RULE 67H:}

Cancellation and suspension of licenses.

1. Licensing authority may, after issuing a show- cause notice, cancel/suspend licence for a certain period.

2. Appeal to State Govt. within 3 months, whose decision is final.

\section{PART VII - A: MANUFACTURE FOR SALE OF HOMEOPATHIC MEDICINES}

(Mandal, PP. et al., 2019; Goel, 2016; Anonymous, 2020).

\section{RULE 85A:}

Manufacture on more than one premises Application for an issue of separate licence in respect of each place.

\section{RULE 85B:}

Application for licence to manufacture.

1. Application for grant/renewal of licenses to made in Form $24 \mathrm{C}$ to the Licensing authority appointed by the State Govt.

2. Application in Form 24C shall accompany:-

- A fee of Rs.200/- for the manufacture of Homeopathic Qs and potent medicines and an inspection fee of Rs.100/- for 1st inspection and Rs.50/ in case of inspection for renewal.

- A fee of Rs.200/- for the manufacture of Homeopathic potent medicines and an inspection fee of Rs.100/- for 1st inspection and Rs.50/ in case of inspection for renewal.

- A fee of Rs.200/- for the manufacture of potent medicines from back potencies of pharmacies already licensed and an inspection fee of Rs.100/- for 1st inspection and Rs.50/ in case of inspection for renewal.

3. Application for renewal after expiry but within 6 months with a fee of:-

- Rs.200/- + Rs.100/- per month and an inspection fee of Rs. 50/ for the manufacture of Homeopathic Qs and potent medicines.

- Rs.200/- + Rs.100/- per month and an inspection fee of Rs. 50/ for the manufacture potent Medicines

- Rs.200/- + Rs.100/- per month and an inspection fee of Rs.50/ for the manufacture of potent medicines from back potencies of pharmacies already licensed.

4. A fee of Rs.50/- to be paid for the duplicate copy.

5. To manufacture additional items a fee of Rs.50/- to be paid for each additional item.

\section{RULE 85C:}

Application to manufacture New Homeopathic Medicine 
1. No New Homeopathic Medicine shall be manufactured unless it is approved by the Licensing authority mentioned in Rule 21.

2. To produce documents and evidence when applying to the Licensing authority for assessing the therapeutic efficacy of the medicine including the minimum proving carried out with it.

3. To produce evidence when applying to the Licensing authority that the New Homeopathic Medicine has already been approved.

\section{RULE 85D:}

Form of licence to manufacture Homeopathic Medicine Licence issued in Form 25C.

\section{RULE 85E:}

Conditions for grant / renewal of licence.

1. Manufacture shall be conducted under the direction and supervision of at least one full time competent technical staff.

2. Factory premises shall comply with the requirements and conditions specified in Schedule M-I.

3. The applicant for manufacture of Homeopathic mother tinctures shall either (i) Have arrangements for identifying raw materials and for testing Qs (Quantum satis). (ii) Make arrangements with some institution approved by Licensing Authority (LA).

4. Premises shall be distinct and separate from the residential area.

5. Shall not manufacture Homeopathic Medicine simultaneously with drugs of other system.

6. Make arrangements for proper storage. www.experthomeo.com

\section{RULE 85EA:}

Inspection before grant/renewal of licence.

To inspect premises, plant, appliances, process of manufacturing, standardizing, testing and professional qualification.

\section{RULE 85EB:}

Report by Inspector shall forward a detailed report to LA.

\section{RULE 85EC:}

Grant / refusal of licence

1. Granted if LA is satisfied

2. If not satisfied LA shall reject the application and inform the applicant of the reasons.

\section{RULE 85ED:}

Further application after rejection Within 6 months from the rejection one can apply after fulfilling the conditions with deposit of Rs.250/- as inspection fee.

\section{RULE 85EF:}


Appeal to the State Govt. Aggrieved person may within 90 days apply 85F: Duration of licence 5 yrs. from the date it is granted / renewed 85G: Certificate of renewal Application for renewal in Form 25C Licence issued in Form 26C

\section{RULE 85H:}

Conditions of licence.

1. To provide and maintain staff and premises as specified in Rule 85E.

2. To allow an Inspector to inspect the premises and take samples

3. To allow an Inspector to inspect registers and records and supply such information as he may require

4. To maintain an Inspection Book in Form 35 to enable an Inspector to record his impressions

5. The licensee shall comply with the following conditions in respect of mother tinctures manufactured (Qs): (i) to identify crude drugs and keep record of identification for 5 yrs (ii) to determine total solids of Qs and keep record for 5 yrs (iii) to determine alcohol content of Qs and keep record for 5 yrs (iv) to use clean, neutral glass containers (v) to maintain hygienic condition during the process of manufacture, storage and handling

6. To add no color to any Homeopathic Medicine.

7. To maintain records of Homeopathic Medicines containing alcohol and the qtys. with names and addresses of parties for 5 yrs.

\section{Rule 85HH:}

Additional information to be furnished Documentary evidence in respect of the ownership/ occupation on rental / other basis of the premises 85-I: Cancellation and suspension of licenses.

1. Licensing authority may, after issuing a show-cause notice, cancel/suspend licence for a certain period.

2. A licensee may apply within 3 months of the date of order against that order to the State Govt.

\section{PART IX - A: LABELLING and PACKING OF HOMEOPATHIC MEDICINES RULE 106A:}

Manner of labeling of Homeopathic Medicines.

To appear following particulars either printed or in indelible ink in a conspicuous manner on the label of the innermost container and any other covering of the packing;

1. The words 'Homeopathic Medicine'

2. Name of the medicine- for drugs included in pharmacopoeias the name specified in particular pharmacopoeia and for other drugs, the name descriptive of the real nature of the drug. 
3. Potency of the Homeopathic medicine either in decimal, centesimal or millesimal system. In case of Homeopathic medicine containing two/more ingredients, the name of each ingredient with its potency and proportion in metric system.

4. Name and address of manufacturer / seller (v) alcohol in \% by volume, if the container is $30 \mathrm{ml} /$ more.

In addition to the above label shall display the following;

A distinctive batch number by the words "Batch No." or "batch" or "Lot Number" or "Lot No." or "Lot" or any distinguishing prefix. And manufacturing licence number by the words "Manufacturing Licence Number" or "Mfg. Lic. No.” or "M.L."

No Homeopathic medicine containing a single ingredient shall bear a proprietary name.

\section{RULE 106B:}

Prohibition of quantity and percentage No Homeopathic medicine containing more than $12 \%$ alcohol $\mathrm{v} / \mathrm{v}$ shall be packed and sold in packing more than $30 \mathrm{ml}$ except to hospitals / dispensaries in packing not more than $100 \mathrm{ml}$.

\section{Who Regulates Homeopathy in India?}

The Central Council of Homeopathy $(\mathrm{CCH})$ is a statutory body under the Ministry of AYUSH, Government of India regulates Homeopathy in India. It was set up by the Government of India in 1973, and is one of the Professional Councils of University Grants Commission (UGC), formed to monitor higher education in India. The $\mathrm{CCH}$ constituted as per 'The Homeopathy Central Council Act 1973' (Legislative Dept., 2020).

Table 2: Content of 'The Homeopathy Central Council Act 1973'

\begin{tabular}{lll}
\hline Chapter & Content & Section \\
\hline I & Preliminary & 1 and 2 \\
II & The Central Council And its Committees & 3 TO 12 \\
IIA & & 12A and 12 B \\
III & Recognition of Medical Qualifications & 13 TO 20 \\
IV & The Central Register of Homeopathy & 21 TO 28 \\
V & Miscellaneous & 29 TO 33 \\
& The First Schedule, The Second Schedule & \\
& The Third Schedule. & \\
\hline
\end{tabular}

Some important Provision of The Homeopathy Central Council Act 1973 elaborated as;

Board, means a Board, Council, Examining Body or Faculty of Homeopathy (by whatever name called) constituted by the State Government under any law for the time being in force regulating the award of medical qualifications in, and registration of practitioners of, Homeopathy.

Central Council, means the Central Council of Homeopathy constituted under section 3 of this Act. 
Central Register of Homeopathy means the register maintained by the Central Council under this Act.

Homeopathy means the Homeopathic system of medicine and includes the use of Biochemical remedies.

Medical Institution means any institution within or without India which grants degrees, diplomas or licenses in Homeopathy;

Recognized Medical Qualification means any of the medical qualifications, in Homeopathy, included in the Second or the Third Schedule of this Act.

State Register of Homeopathy, means a register or registers maintained under any law for the time being in force in any State regulating the registration of practitioners of Homeopathy.

Table 3: Constitution of Central Council of Homeopathy $(\mathrm{CCH})$

Elected
1. Such number of members not exceeding

The President and the Vice-President of the Central Council shall be elected by the members of the Central Council from amongst themselves in such manner as may be prescribed.

Term of office of President, Vice-President and members of Central Council (Legislative Dept., 2020)

1. The President, Vice-President or a member of the Central Council shall hold office for a term of five years from the date of his election or nomination, as the case may be, or until his successor shall have been duly elected or nominated, whichever is longer. A person who holds, or who has held, office as President or Vice-President of the Central Council, shall be eligible for re-election to that office once, but only once. Members of the Central Council shall be eligible for re-election or re-nomination. An elected or nominated member shall be deemed to have vacated his seat if he is absent without excuse, sufficient in the opinion of the Central Council, from three consecutive ordinary meetings of the Central Council. A casual vacancy in the Central Council shall be filled by election or nomination, as the case may be, and the person elected or nominated to fill the vacancy shall hold office only for the remainder of the 
term for which the member whose place he takes was elected or nominated. Where the said term of five years is about to expire in respect of any member, a successor may be elected or nominated at any time within three months before the said term expires but he shall not assume office until the said term has expired.

Table 4: Current Central Council of Homeopathy (CCH)

\begin{tabular}{|c|c|}
\hline President & $\begin{array}{l}\text { Ministry of AYUSH, Govt. of India has appointed Board of Governors to } \\
\text { exercise the powers and to perform the functions of the Council under HCC } \\
\text { Act, 1973, vide Gazette Notification No. R-13040/61/2017-HD (Tech) dated } \\
\text { 18.05.2018. }\end{array}$ \\
\hline $\begin{array}{l}\text { Vice } \\
\text { president }\end{array}$ & $\begin{array}{l}\text { Ministry of AYUSH, Govt. of India has appointed Board of Governors to } \\
\text { exercise the powers and to perform the functions of the Council under HCC } \\
\text { Act, 1973, vide Gazette Notification No. R-13040/61/2017-HD (Tech) dated } \\
\text { 18.05.2018. }\end{array}$ \\
\hline Members & $\begin{array}{l}\text { Ministry of AYUSH, Govt. of India has appointed Board of Governors to } \\
\text { exercise the powers and to perform the functions of the Council under HCC } \\
\text { Act, 1973, vide Gazette Notification No. R-13040/61/2017-HD (Tech) dated } \\
\text { 18.05.2018. }\end{array}$ \\
\hline
\end{tabular}

\section{The Executive Committee and other committees}

The Central Council shall constitute from amongst its members an Executive Committee and such other committees for general or special purposes as the Council deems necessary to carry out the purposes of this Act. The Executive Committee shall consist of the President and VicePresident, who shall be members ex officio, and not less than five and not more than seven members who shall be elected by the Central Council from amongst its members. The President and the Vice-President shall be the President and Vice-President respectively of the Committee. In addition to the powers and duties conferred and imposed upon it by this Act, the Committee shall exercise and discharge such powers and duties as the Central Council may confer or impose upon it by any regulations which may be made in this behalf (Legislative Dept., 2020).

\section{Non-Recognition of Medical Qualifications in certain Cases in Homeopathy}

1. Where any medical institution is established without the previous permission of the Central Government in accordance with the provisions of Act, medical qualification granted to any student of such medical institution shall not be deemed to be a recognized medical qualification for the purposes of this Act.

2. Where any medical institution opens a new or higher course of study or training (including a post-graduate course of study or training) without the previous permission of the Central Government in accordance with the provisions of Act, medical qualification granted to any student of such institution on the basis of such study or training shall not be deemed to be recognized medical qualification for the purposes of this Act. 
3. Where any medical institution increases its admission capacity in any course of study or training without the previous permission of the Central Government in accordance with the provisions of Act, medical qualification granted to any student of such medical institution on the basis of the increase in its admission capacity shall not be deemed to be recognized medical qualification for the purposes of this Act (Legislative Department, 2020).

\section{Recognition of Medical Qualification Granted by certain Medical Institutions in India FOR Homeopathy}

1. The medical qualifications granted by any University, Board or other medical institution in India which are included in the Second Schedule shall be recognized medical qualifications for the purposes of this Act.

2. Any University, Board or other medical institution in India which grants a medical qualification not included in the Second Schedule may apply to the Central Government to have any such qualification recognized, and the Central Government, after consulting the Central Council, may, by notification in the Official Gazette, amend the Second Schedule so as to include such qualification therein, and any such notification may also direct that an entry shall be made in the last column of the Second Schedule against such medical qualification only when granted after a specified date (Legislative Dept., 2020).

\section{Recognition of Medical Qualifications granted by Medical Institutions in States or Countries outside India for Homeopathy}

1. The medical qualifications granted by medical institutions outside India which are included in the Third Schedule shall be recognized medical qualifications for the purposes of this Act.

2. The Central Council may enter into negotiations with the authority in any State or country outside India, which by the law of such State or country is entrusted with the maintenance of a Register of practitioners of Homeopathy, for settling of a scheme of reciprocity for the recognition of medical qualifications in Homeopathy, and in pursuance of any such scheme, the Central Government may, by notification in the Official Gazette, amend the Third Schedule so as to include therein any medical qualification which the Central Council has decided should be recognized, and any such notification may also direct that an entry shall be made in the last column of the Third Schedule against such medical qualification declaring that it shall be a recognized medical qualification only when granted after a specified date.

3. Where the Council has refused to recommend any medical qualification which has been proposed for recognition by any authority referred to in above point (1) and that 
authority applies to the Central Government in this behalf, the Central Government, after considering such application and after obtaining from the Council a report, if any, as to the reasons for any such refusal, may, by notification in the Official Gazette, declare that such qualification shall be a recognized medical qualification and the provisions of (1) shall apply accordingly (Legislative Department, 2020).

\section{Minimum Standards of Education in Homeopathy}

1. The Central Council may prescribe the minimum standards of education in Homeopathy, required for granting recognized medical qualifications by Universities, Boards or medical institutions in India.

2. Copies of the draft regulations and of all subsequent amendments thereof shall be furnished by the Central Council to all State Governments and the Central Council shall, before submitting the regulations or any amendment thereof, as the case may be, to the Central Government for sanction, take into consideration the comments of any State Government received within three months from the furnishing of the copies as aforesaid (Goel, 2016).

\section{The Central Register of Homeopathy}

1. The Central Council shall cause to be maintained in the prescribed manner, a register of practitioners of Homeopathy to be known as the Central Register of Homeopathy which shall contain

- in Part I, the names of all persons who are for the time being enrolled on any State Register of Homeopathy and possess any of the recognized medical qualifications;

- in Part II, the names of all persons, other than those included in Part I, who are for the time being enrolled on any State Register of Homeopathy.

2. It shall be the duty of the Registrar of the Central Council to keep and maintain the Central Register of Homeopathy in accordance with the provisions of this Act and of any orders made by the Central Council, and from time to time to revise the register and publish it in the Gazette of India and in such other manner as may be prescribed.

3. Such register shall be deemed to be a public document within the meaning of the Indian Evidence Act, 1872 ( 1 of 1872), and may be proved by a copy published in the Gazette of India (Legislative Dept., 2020)

\section{Registration in the Central Register of Homeopathy}

The Registrar of the Central Council may on receipt of the report of registration of a person in a State Register of Homeopathy or on application made in the prescribed manner by any person, enter his name in the Central Register of Homeopathy, provided that the Registrar is satisfied that the person concerned is eligible under this Act for such registration. 


\section{Professional Conduct of Homeopathy}

1. The Central Council may prescribe standards of professional conduct and etiquette and a code of ethics for practitioners of Homeopathy.

2. Regulations made by the Central Council under Act may specify which violations thereof shall constitute infamous conduct in any professional respect, that is to say, professional misconduct, and such provision shall have effect notwithstanding anything contained in any law for the time being in force.

\section{Removal of Names from the Central Register of Homeopathy}

1. If the name of any person enrolled on a State Register of Homeopathy is removed there from in pursuance of any power conferred by or under any law relating to registration of practitioners of Homeopathy for the time being in force in any State, the Central Council shall direct the removal of the name of such person from the Central Register of Homeopathy.

2. Where the name of any person has been removed from a State Register of Homeopathy on any ground other than that he is not possessed of the requisite medical qualifications or where any application by the said person for restoration of his name to the State Register of Homeopathy has been rejected, he may appeal in the prescribed manner and subject to such conditions, including conditions as to the payment of a fee, as may be prescribed, to the Central Government whose decision, which shall be given after consulting the Central Council, shall be binding on the State Government and on the authorities concerned with the preparation of the State Register of Homeopathy.

\section{THE FIRST SCHEDULE}

The Central Government shall, by notification in the Official Gazette, determine the number of seats allocated in the Central Council of Homeopathy in each State on the following basis,

1. Where the number of persons enrolled on a State Register of Homeopathy system exceeds 100 but does not exceed 10,000 then 1 seats.

2. Where the number of persons enrolled on a State Register of Homeopathy system exceeds 10,000 but does not exceed 20,000 then 2 seats.

3. Where the number of persons enrolled on a State Register of Homeopathy system exceeds 20,000 but does not exceed 30,000 then 3 seats.

4. Where the number of persons enrolled on a State Register of Homeopathy system exceeds 30,000 but does not exceed 40,000 then 4 seats.

5. Where the number of persons enrolled on a State Register of Homeopathy system exceeds 40,000 then 5 seats. 
For every subsequent election to the Central Council under Act, the Central Government shall, by notification in the Official Gazette, determine the number of seats allocated in the Central Council of Homeopathy on the basis laid down in paragraph 1 above.

\section{THE SECOND SCHEDULE}

Recognized Medical Qualifications in Homeopathy Granted By Universities, Boards or Medical Institutions in India.

\section{THE THIRD SCHEDULE}

Qualifications Granted by Medical Institutions outside India.

\begin{tabular}{|l|l|}
\hline $\begin{array}{l}\text { Name of University, Board or } \\
\text { Medical Institution }\end{array}$ & Recognized medical qualification \\
\hline Faculty of Homeopathy, London. & Diploma of the Faculty of Homeopathy. \\
\hline Faculty of Homeopathy, London. & Member of the Faculty of Homeopathy \\
\hline Faculty of Homeopathy, London. & Fellow of the Faculty of Homeopathy. \\
\hline
\end{tabular}

\section{CONCLUSION}

Homeopathy is an alternative system of medicines having its own philosophy. The present review surely shade light on its legislation and regulation within India. That will be helpful for the academician, industry persons and researcher to proceed further in view of its development in India in coming days.

\section{REFERENCES}

1. Ram Jyothis. https://www.slideshare.net/RamJyothis/legislation-in-respect-ofhomeopathic-pharmacy, Retrieved on 12/03/2020.

2. Tayyeba Rehman and Saeed Ahmad, Introduction of Homeopathy and Homeopathic Medicines: A review, International Journal of Homeopathic Sciences 2017; 1(1): 2125.

3. Mukherjee PK, Wahile A. Integrated approaches towards drug development from Ayurveda and other Indian system of medicines. Journal of Ethnopharmacology. 2006; 103:25-35.

4. Ministry of AYUSH. ANNEXURE-I, Advisory from Ministry Of AYUSH for Meeting the Challenge Arising Out Of Spread of Corona Virus (Covid-19) In India. D.O.NO.S. 16030/18/19-NAM: Dated: $6^{\text {th }}$ Mach 2020.

5. Anonymous. https://www.experthomeo.com/legislation-in-respect-of-homoeopathicpharmacy/ Retrieved on 02/06/2020.

6. Legislative Dept., Government of India. http://legislative.gov.in/sites/default/files/A1973-59.pdf. Retrieved on 18/04/2020.

7. Wayne Jonas, MD. A Critical Overview of Homeopathy. 21 October 2003 https://www.acpjournals.org/doi/pdf/10.7326/0003-4819-139-8-200310210-00026-w4 
8. Ernst E. A Systematic Review of Systematic Reviews of Homeopathy. British J of Clinical Pharmacology, 2002; 54: 577-582. https://doi.org/10.1046/j.13652125.2002.01699.x

9. Vigano, G., Nannei, P. and Bellavite, P. Homeopathy: from tradition to science? J Med Pers. 2015; 13: 7-17. https://doi.org/10.1007/s12682-014-0197-y.

10. Wayne JB., Klaus Linde, Gilbert Ramirez. Homeopathy and Rheumatic Disease. Homeopathic Disease Clinics of North America, 1 February 2000; 26(1):117-123. https://doi.org/10.1016/S0889-857X(05)70125-3.

11. Mandal, PP., Mandal, B. A Textbook of Homeopathy Pharmacy, New Central Book Agency (P) Ltd, Kolkata, $3^{\text {rd }}$ Ed. 2012 Reprinted 2019; 448-471.

12. Goel Sumit, Art and Science of Homeopathic pharmacy. Homoeopathic Community, $3^{\text {rd }}$ Ed., 2016; 423-443.

13. Kuchekar, BS. Pharmaceutical Jurisprudence. Nirali Publication, Pune, $13^{\text {th }}$ Ed., 2008; 5.10-5.43.

14. Singh, SK., Ushir, YV, and Katare, YS. Text book of Pharmaceutical Jurisprudence, Everest Publishing House, Pune, $1^{\text {st }}$ Ed., 2017; 4, 10-11, 43-44.

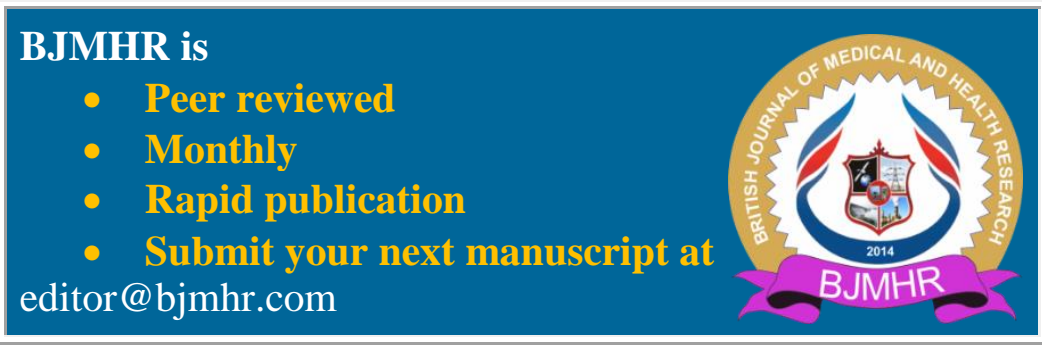

